\title{
SALINITY REDUCED GROWTH PS2 PHOTOCHEMISTRY AND CHLOROPHYLL CONTENT IN RADISH
}

\author{
Muhammad Jamil ${ }^{1}$; Shafiq ur Rehman²; Kui Jae Lee ${ }^{3}$; Jeong Man Kim4; Hyun-Soon Kim; \\ Eui Shik Rha ${ }^{1 *}$ \\ ${ }^{1}$ College of Agriculture and Life Sciences, Sunchon National University, Suncheon - 540-742 - Korea. \\ ${ }_{3}^{2}$ Kohat University of Science and Technology, Department of Botany, Kohat NWFP, Pakistan. \\ ${ }_{4}^{3}$ College of Agriculture and Life Science, Chonbuk National University, Jeonju - 561-756 - Korea. \\ ${ }_{5}^{4}$ Jeollabuk-Do Agricultural Research and Extension Service - Iksan 570-704 - Korea. \\ ${ }^{5}$ International Technical Cooperation Center, Research and Development Bureau, RDA, Suwon - 441- 707- Korea. \\ *Corresponding author <euishik@sunchon.ac.kr>
}

\begin{abstract}
When plants are grown under saline conditions, photosynthetic activity decreases leading to reduced plant growth, leaf area, chlorophyll content and chlorophyll fluorescence. Seeds and seedlings of radish (Raphanus sativus L.) were grown in $\mathrm{NaCl}$ solutions under controlled greenhouse conditions. The $\mathrm{NaCl}$ concentrations in complete nutrient solutions were 0 (control), 4.7, 9.4 and $14.1 \mathrm{dS} \mathrm{m}^{-1}$. The salinity reduced germination percentage and also delayed the germination rate as the salt level increased. Lengths and fresh weights of root and shoot decreased with the increasing salt concentration. Furthermore, photochemical efficiency of PS2 $\left(\mathrm{F}_{\mathrm{v}} / \mathrm{F}_{\mathrm{m}}\right)$, photochemical quenching coefficient $\left(\mathrm{q}_{\mathrm{p}}\right)$, non photochemical quenching coefficient $\left(\mathrm{q}_{\mathrm{N}}\right)$, leaf area and chlorophyll content (SPAD value) were also reduced $(P \leq 0.001)$ by salt stress. In contrast, the Fo/Fm ratio increased with increasing salt concentration while salinity showed no effect on the efficiency of excitation captured by open PS2 (Fv'/Fm'), electron transport rate (ETR), and leaf water content. Linear regression shows that the photochemical efficiency of PS2 $\left(\mathrm{F}_{\mathrm{v}} / \mathrm{F}_{\mathrm{m}}\right)$ had a positive relationship with the photochemical quenching coefficient $\left(\mathrm{q}_{\mathrm{p}}\right)$, leaf area and chlorophyll content but had no relation with Fv'/Fm', Fo/Fm, and $\mathrm{q}_{\mathrm{N}}$

Key words: Raphanus sativus L., plant growth, photosynthesis, leaf area
\end{abstract}

\section{CRESCIMENTO REDUZIDO POR SALINIDADE, FOTOQUÍMICA PS2 E CONTEÚDO DE CLOROFILA EM RABANETE}

\begin{abstract}
RESUMO: Quando plantas crescem sob condições de salinidade, sua atividade fotossintética diminui levando a um crescimento reduzido, menor área foliar, conteúdo de clorofila e fluorescência de clorofila. Sementes e plântulas de rabanete (Raphanus sativus L.) foram germinadas e conduzidas em soluções de $\mathrm{NaCl}$ sob condições controladas de casa de vegetação. As concentrações de $\mathrm{NaCl}$ adicionado a solução nutritiva completa foram 0 (Controle), 4,7; 9,4 e 14,1 dS m${ }^{-1}$. A salinidade diminui a percentagem de germinação e também atrasou a taxa de germinação com o aumento do nível de sal. Comprimento e peso fresco da parte aérea e da raiz decresceram com o aumento da concentração salina. Além disso, a eficiência fotoquímica de PS2 $\left(\mathrm{F}_{\mathrm{v}} / \mathrm{F}_{\mathrm{m}}\right)$, o coeficiente fotoquímico de "quenchin" $\left(\mathrm{q}_{\mathrm{p}}\right)$, o coeficiente não fotoquímico de "quenching" $\left(\mathrm{q}_{\mathrm{n}}\right)$, a área foliar e o teor de clorofila (valor SPAD) também foram reduzidos $(P \leq 0,001)$ por estresse de sal. Ao contrário, a relação Fo/Fm aumentou com a concentração salina, ao passo que a salinidade não teve efeito sobre a eficiência de excitação capturada pelo PS2 aberto (Fv'/Fm'), taxa de transporte eletrônico (ETR) e conteúdo de água na folha. Através de regressão linear mostrou-se que a eficiência fotossintética de PS2 $\left(\mathrm{F}_{\mathrm{v}} / \mathrm{F}_{\mathrm{m}}\right)$ teve uma relação positiva com o coeficiente fotoquímico de "quenching" $\left(\mathrm{q}_{\mathrm{p}}\right)$, área foliar e conteúdo de clorofila, mas nenhuma relação com (Fv/Fm), (Fo/Fm), e $\mathrm{q}_{\mathrm{n}}$. Palavras-chaves: Raphanus sativus L., crescimento vegetal, fotossíntese, área foliar
\end{abstract}

\section{INTRODUCTION}

Salinity is one of the major obstacles for increasing production in cropping areas throughout the world. There have been numerous reviews of the effects of salinity on plant physiological processes and subsequent effects on yield (Greenway \& Munns, 1980; Shannon et al., 1994; Neumann, 1995). In spite of this extensive literature there is still a controversy with regard to the mechanisms of salt tolerance in plants (Neumann, 1995).

The growth of plants is ultimately reduced by salinity stress although plant species differ in their tol- 
erance to salinity (Munns \& Termaat, 1986). Successful seedling establishment depends on the frequency and the amount of precipitation as well as on the ability of the seed species to germinate and grow while soil moisture and osmotic potentials decrease (Roundy, 1985). High levels of soil salinity can inhibit seed germination and seedling growth, due to the combined effects of high osmotic potential and specific ion toxicity (Grieve \& Suarez, 1997).

The decline in productivity observed for many plant species subjected to excess salinity is often associated with the reduction in photosynthesis capacity (Long \& Baker, 1986). Salts taken up by plants may not directly control their growth by affecting turgor, photosynthesis or enzyme activities rather then buildup of salt in old leaves may hasten leaf death (Munns, 1993). The reduction in photosynthesis under salinity can also be attributed to a decrease in chlorophyll content. Salinity reduces the chlorophyll content in salt susceptible plants and increases in salt tolerant plants. Salinity reduced growth in radish (Raphanus sativus L.) at high salinity level could be attributed to a reduction in leaf area expansion and hence to a lower light interception (Marcelis \& Hooijdonk, 1999).

The objective of this study was to observe the effect of salinity on the germination and early seedling growth through measurements of leaf area, PS2 photochemistry and chlorophyll content after seedling stage in radish and also to find the relationship between photochemical efficiency of PS2 $\left(\mathrm{F}_{\mathrm{v}} / \mathrm{F}_{\mathrm{m}}\right)$ and other photosynthesis parameters under salt stress condition.

\section{MATERIAL AND METHODS}

Radish was investigated for its salt tolerance during germination and growth stage in two experiments:

\section{Salinity effect on germination and early seedling growth}

One experiment was conducted to observe the effect of salinity on radish during germination and early seedling stage, by using Petri dishes $(87 \mathrm{~mm}$ diameter, $15 \mathrm{~mm}$ height) with two Whatman No 2 filter papers soaked with $10 \mathrm{~mL}$ of distilled water or $4.7 \mathrm{dS} \mathrm{m}^{-1}$, $9.4 \mathrm{dS} \mathrm{m}^{-1}$ and $14.1 \mathrm{dS} \mathrm{m}^{-1} \mathrm{NaCl}$ concentrations. Five replicate dishes with 20 seeds were used for each treatment. Seeds were hand sorted to eliminate broken and small seeds. Germination percentage and germination rate $\left(1 / t_{50}\right.$, where $t_{50}$ is the time for $50 \%$ of germination) were determined. Seed germination was evaluated after every 12 hours. After 48 hours seeds had started to germinate (seeds were considered to be germinated with the emergence of the root tip). The germinating seeds were counted at regular intervals. The lengths and fresh weights of root and shoot of the germinated seeds were observed and recorded after 15 days. Root and shoot length was measured manually.

A second experiment was established to investigate the salinity effect on leaf area, PS2 photochemistry and chlorophyll content. Seeds were grown in plastic pots $(16 \mathrm{~cm}$ diameter, $22 \mathrm{~cm}$ height) in sand culture. $\mathrm{NaCl}$ concentrations (0.0 (control), 4.7, 9.4 and $14.1 \mathrm{dS} \mathrm{m}^{-1}$ ) in complete Hoagland's nutrient solution (Hoagland \& Arnon, 1950) were used to raised plants under greenhouse conditions.

\section{Measurements of PS2 photochemistry}

PS2 photochemistry was measured on attached dark adapted leaves at room temperature with a portable Mini PAM fluorometer (PAM-2000, Walz, Germany). A data acquisition software (DA- 2000, Walz) was used to connect the fluorometer to a computer. The experimental protocol of Genty et al. (1989) was basically followed in this experiment. The minimal fluorescence level (Fo) was obtained by measuring the modulated light, which was sufficiently low $(<0.1 \mathrm{mmol}$ $\mathrm{m}^{-2} \mathrm{~s}^{-1}$ ) in order not to induce any significant variable change in fluorescence. The maximal fluorescence level (Fm) was measured by a $0.8 \mathrm{~s}$ saturating pulse at 8000 mmol m $\mathrm{s}^{-2} 1$. The measurements of Fo were performed with the beam set to a frequency of $0.6 \mathrm{kHz}$, whereas measurements of Fm were performed with the beam automatically switched to $20 \mathrm{kHz}$ during the saturating flash. The leaves were continuously illuminated with white actinic light at an intensity of $300 \mu \mathrm{mol} \mathrm{m} \mathrm{m}^{-2} \mathrm{~s}^{-1}$. By using fluorescence parameters determined in leaves, the following calculations were made: (1) maximal quantum yield of PS2 photochemistry (Fv/Fm); (2) photochemical quenching coefficient, $\mathrm{q}_{\mathrm{P}}=(\mathrm{M}-\mathrm{F}) /(\mathrm{M}-\mathrm{Fo})(\mathrm{M}$ here represents the maximal fluorescence measured by a saturation pulse in given light state, whereas Fm and Fo are the values sampled after dark adaptation and the non-photochemical quenching coefficient $\mathrm{q}_{\mathrm{N}}=1-\left(\mathrm{Fm}^{\prime}-\mathrm{Fo}^{\prime}\right) /(\mathrm{Fm}-\mathrm{Fo})$; (3) efficiency of excitation captured by open PS2 (Fv'/Fm'); (4) physiological state of the photosynthetic apparatus (Fo/Fm); (5) electron transport rate $(\mathrm{ETR})(\mathrm{ETR}=$ yield $\times \mathrm{QFD} \times 0.5 \times 0.84)$ (the standard factor 0.84 corresponds to the fraction of incident light absorbed by leaf).

\section{Measurements of leaf area and leaf water content} Leaf area of the plant leaves were measured by using an area meter (AM-200), ADC Bio Scientific Ltd., England). After leaf area measurement the fresh weight of leaves was determined and there after they were oven dried at $80^{\circ} \mathrm{C}$ for two days to obtain the dry weight. The leaf water content was calculated as (FW-DW)/FW*100, where FW is leaf fresh weight and DW is leaf dry weight. 


\section{Leaf chlorophyll measurement}

Leaf chlorophyll content was measured using a hand-held chlorophyll content meter (CCM-200, Opti-Science, USA). At each evaluation the content was measured 6 times from leaf tip to base and the average was used for analysis.

Analysis of variance was made using the MSExcel Statistical software and linear regression by the Minitab statistical package. Mean values for germination and early seedling growth, PS2 photochemistry parameters, chlorophyll content, leaf area and leaf water content were compared by their LSD using Tukey's test $(\mathrm{Li}, 1964)$.

\section{RESULTS}

\section{Salinity effect on early growth stages}

Germination percentage was strongly affected by all salinity concentrations (Figure 1A). Increased salt concentration caused a decrease in final germination percentage. A marked reduction in germination was observed at $9.4 \mathrm{dS} \mathrm{m}^{-1}$ and $14.1 \mathrm{dS} \mathrm{m}^{-1}$
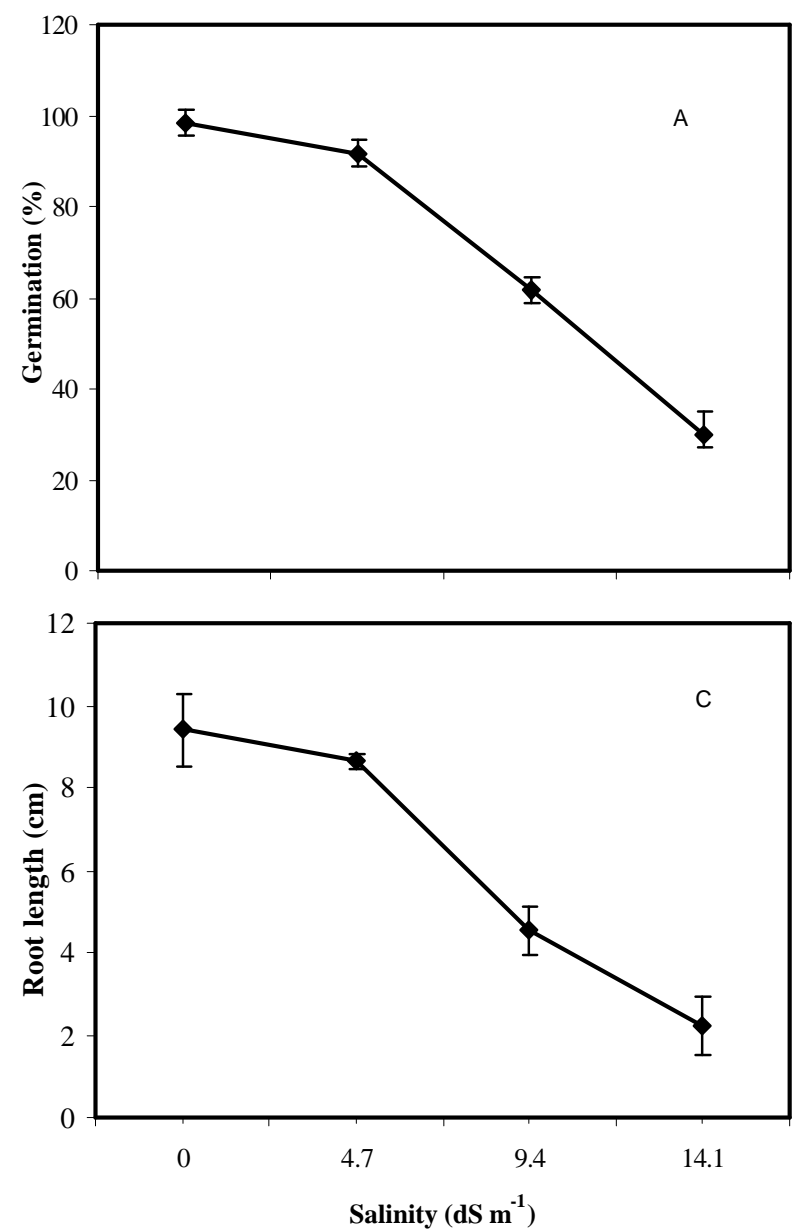

$\mathrm{NaCl}$ (Figure 1A), however germination response to $4.7 \mathrm{dS} \mathrm{m}^{-1} \mathrm{NaCl}$ did not differ from control. Similarly, germination was delayed with the increase of $\mathrm{NaCl}$ concentration (Figure 1B). The final germination rate under various conditions of salinity was expressed as $1 / t_{50}$ of the germination of the seeds of the same population in relation to control. A marked difference was found in the time of germination start and completion under various $\mathrm{NaCl}$ concentrations. Overall germination started within 48 hours and completed on the $7^{\text {th }}$ day (Figure 1B).

Salinity caused delayed emergence of root and shoot as compared to control. The continuous increase in length of root and shoot was detected in frequent hours in the control as well as in salt treatments. The data on the average lengths (Figures 1C, 1D) of root and shoot shows a strong inhibition with the increasing level of salt solution. Salinity caused a reduction in seedling growth. Significant $(P<0.001)$ growth reduction occurred at $4.1 \mathrm{dS} \mathrm{m}^{-1}$ and at higher $\mathrm{NaCl}$ concentrations. The root length decreased more pronouncedly as compared to shoot in
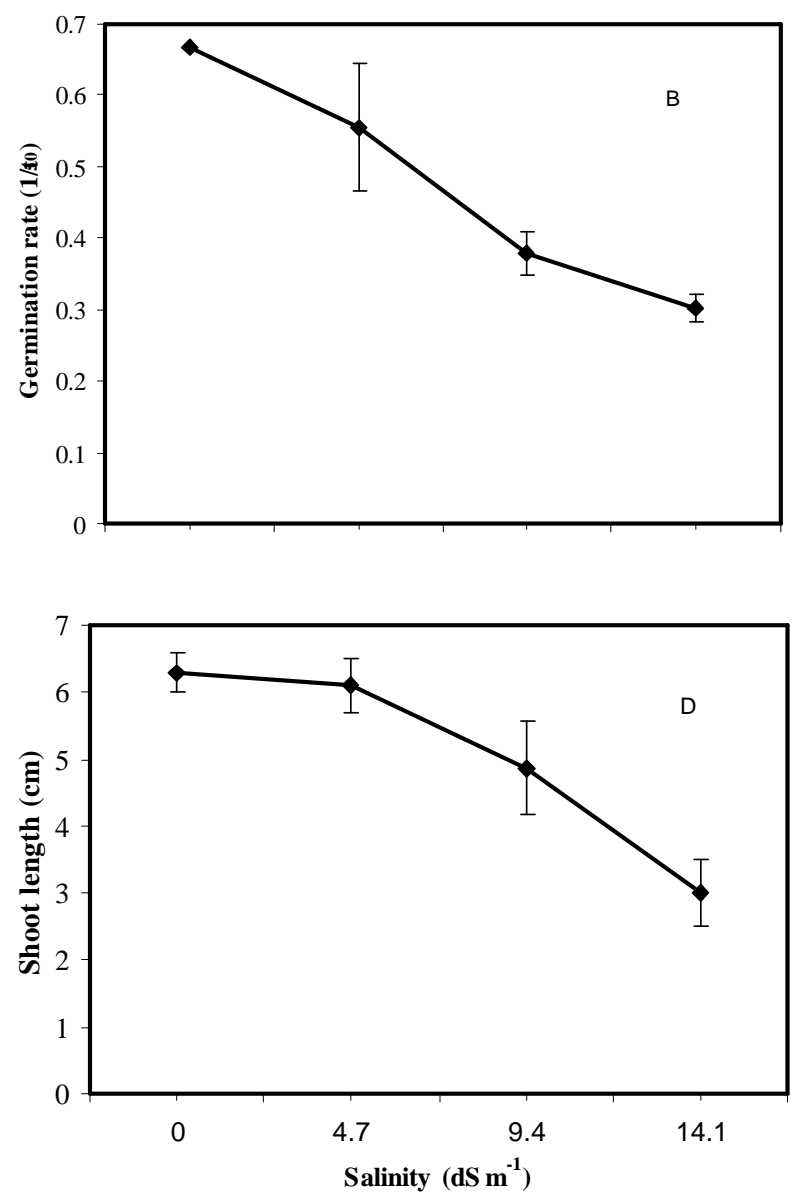

Figure 1 - Salinity effect on germination percentage (A) germination rate (B) root length (C) and shoot length (D) at various Na concentrations for radish (Raphanus sativus L.). 
all $\mathrm{NaCl}$ treatments (Figures 1C, 1D). Highly significant differences were also observed in the fresh mass of root and shoot (Figures 2A, 2B). Fresh mass of root and shoot was reduced by increasing salt levels, whereas shoot fresh mass was more reduced then root fresh mass.

\section{Salinity effect on PS2 photochemistry}

Maximal quantum yield of PS2 (Fv/Fm) was reduced with the increasing salt concentration especially at high salt concentrations (Figure 3A). The effect of salinity was also observed on the photochemical quenching coefficient $\left(\mathrm{q}_{\mathrm{p}}\right)$ and non-photochemical quenching coefficient $\left(\mathrm{q}_{\mathrm{N}}\right)$. The photochemical quenching coefficient $\left(\mathrm{q}_{\mathrm{p}}\right)$ and non-photochemical quenching coefficient $\left(\mathrm{q}_{\mathrm{N}}\right)$ decreased as the salinity level increased. The rate of decrease was more at the highest concentration for $\mathrm{q}_{\mathrm{p}}$ and $\mathrm{q}_{\mathrm{N}}$ (Figures $4 \mathrm{~A}, 4 \mathrm{~B}$ ). In contrast the $\mathrm{Fo} / \mathrm{Fm}$ ratio increased with salt concentration while no effect was observed for the salinity treatments on the electron transport rate (ETR) and the efficiency of excitation captured by open PS2 (Fv'/Fm') (Figures 3B, 3C, 3D). The pattern of increase or decrease in ETR and Fv'/Fm' were not
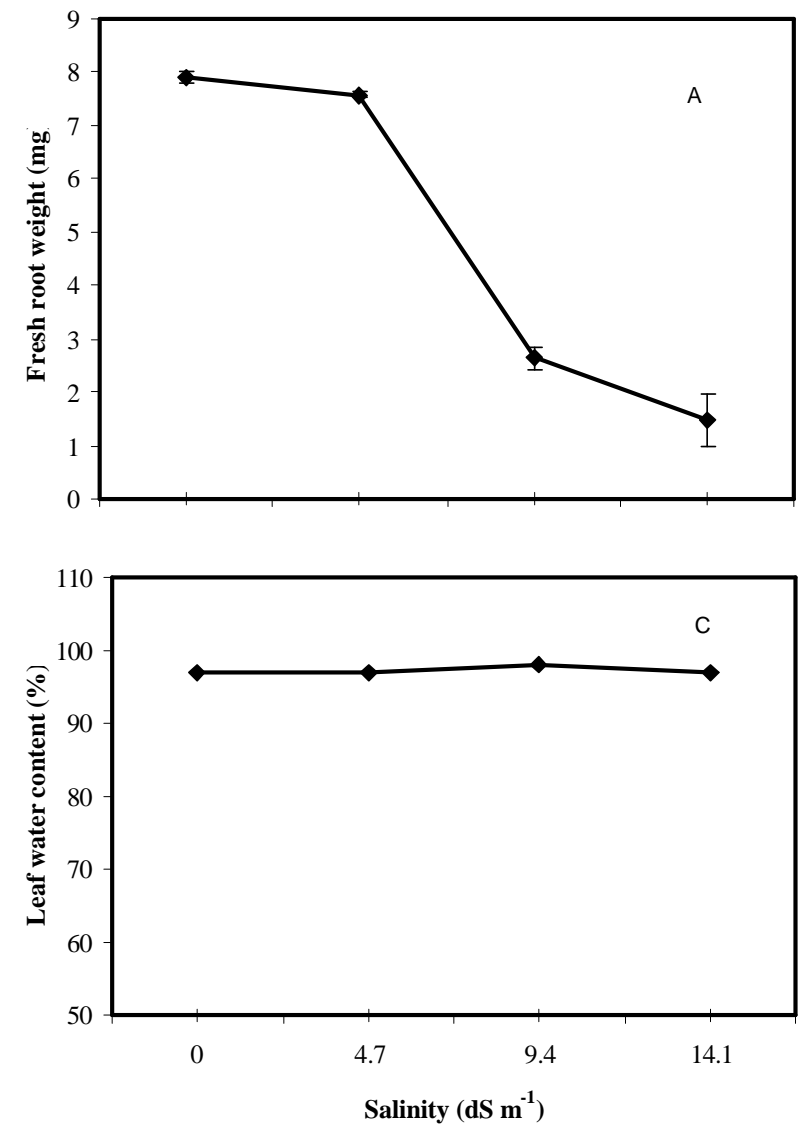

consistent at varying $\mathrm{NaCl}$ concentrations (Figures 3B, 3D).

\section{Salinity effect on leaf area and chlorophyll content}

Salinity concentration caused considerable reduction of leaf area (Figure 2D). A similar pattern of reduction was observed for 9.4 and $14.1 \mathrm{dS} \mathrm{m}^{-1} \mathrm{NaCl}$ while the leaf area was not different between $4.7 \mathrm{dS}$ $\mathrm{m}^{-1} \mathrm{NaCl}$ and control (Figure 2D). Furthermore, $\mathrm{NaCl}$ had no effect on leaf water contents (Figure 2C) but reduced the leaf chlorophyll contents (Figure 4C). The effect of 9.4 and $14.1 \mathrm{dS} \mathrm{m}^{-1} \mathrm{NaCl}$ was far more evident than for $4.7 \mathrm{dS} \mathrm{m}^{-1} \mathrm{NaCl}$ (Figure $4 \mathrm{C}$ ).

Linear regression was used to find the relationship between maximum quantum yield of PS2 and $\mathrm{Fv}^{\prime} / \mathrm{Fm}$ ', Fo/Fm, $\mathrm{q}_{\mathrm{p}}, \mathrm{q}_{\mathrm{N}}$ leaf area and chlorophyll contents (Table 1). Positive relationships were found between $\mathrm{Fv} / \mathrm{Fm}$ and $\mathrm{q}_{\mathrm{p}}$ leaf area and chlorophyll content. A strong significant positive $\left(\mathrm{R}^{2}=0.97, P=0.02\right)$ relationship was observed between $\mathrm{Fv} / \mathrm{Fm}$ and leaf area, and a weak positive $\left(\mathrm{R}^{2}=0.90, P=0.05\right)$ relationship was also found between $\mathrm{Fv} / \mathrm{Fm}$ and $\mathrm{q}_{\mathrm{p}}$. There was also a non significant relationship between yield and Fv'/Fm', Fo/Fm and $\mathrm{q}_{\mathrm{N}}$ (Table 1).
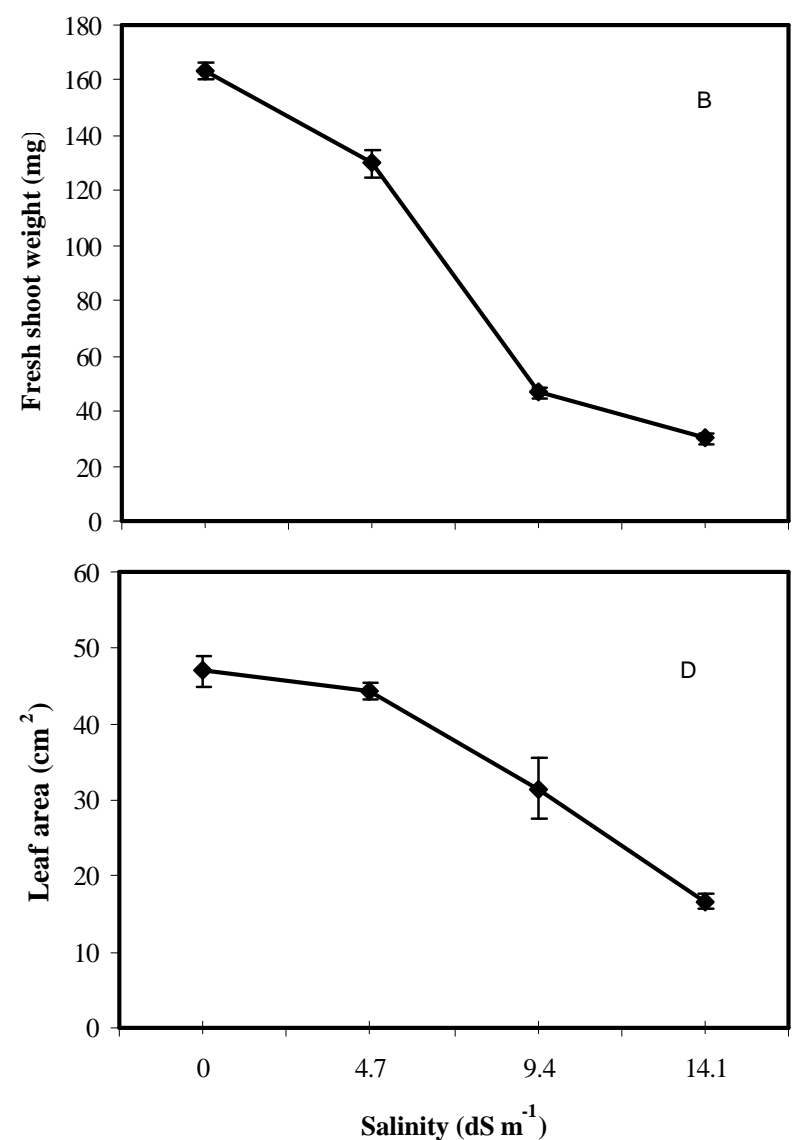

Figure 2 - Salinity effects on fresh root weight (A) fresh shoot weight (B) leaf water content (C) and leaf area (D) at various $\mathrm{NaCl}$ concentrations for radish (Raphanus sativus L.). Error bars are not shown if smaller than symbols. 

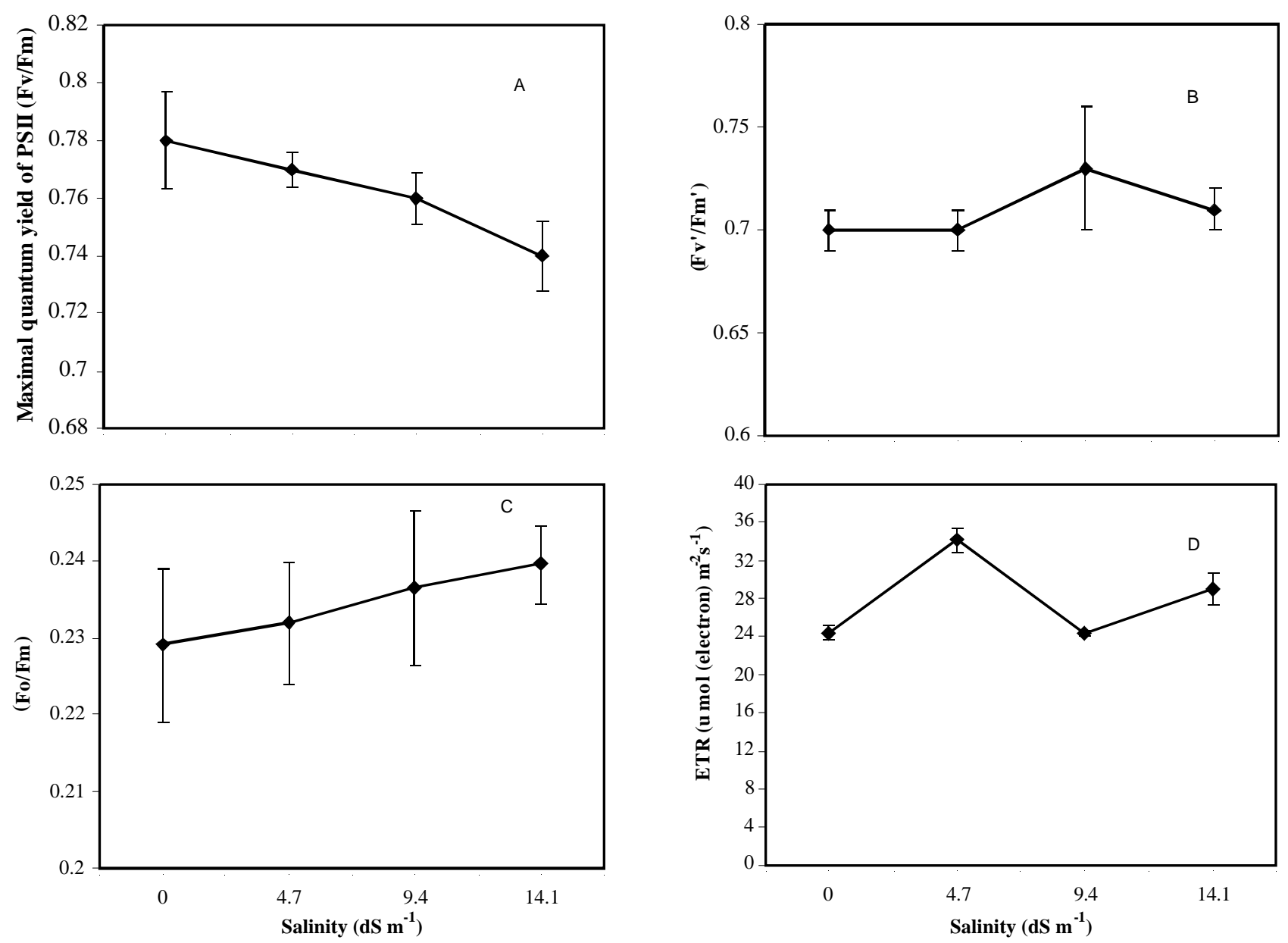

Figure 3 - Salinity effect on the maximum efficiency of PS2 photochemistry (Fv/Fm) (A) efficiency of excitation captured by open PS2 (Fv'/Fm') (B) Fo/Fm ratio (C) and electron transport rate (ETR) (D) at various $\mathrm{NaCl}$ concentrations for radish ((Raphanus sativus L.).

Table 1 - Relation between maximal quantum yield (Y) of PS2 and Fv'/Fm', Fo/Fm, ETR, qP, qN, leaf area and CCI treated with different concentration of salinity.

\begin{tabular}{|c|c|c|c|}
\hline Parameter & Regression equation & Regression coefficient $\left(\mathrm{R}^{2}\right)$ & Probability \\
\hline $\mathrm{Fv}^{\prime} / \mathrm{Fm}^{\prime}$ & $Y=-0.417 x+1.06$ & 0.12 & $0.65^{\text {ns }}$ \\
\hline $\mathrm{Fo} / \mathrm{Fm}$ & $Y=-2.69 x+1.38$ & 0.08 & $0.70^{\mathrm{ns}}$ \\
\hline ETR & $Y=-0.002 x+0.78$ & 0.01 & $0.86^{\mathrm{ns}}$ \\
\hline $\mathrm{q}_{\mathrm{P}}$ & $Y=\quad 0.565 x+0.33$ & 0.90 & $0.05^{*}$ \\
\hline $\mathrm{q}_{\mathrm{N}}$ & $0.523 x+0.34$ & 0.89 & $0.06^{\mathrm{ns}}$ \\
\hline Leaf area & $0.001 x+0.73$ & 0.97 & $0.02^{*}$ \\
\hline $\mathrm{CCI}$ & $782 x+566$ & 0.93 & $0.03^{*}$ \\
\hline
\end{tabular}

$\mathrm{x}$-Denotes the parameters in the linear equation; ns - Non significant; *Significant

\section{DISCUSSION}

Increasing $\mathrm{NaCl}$ concentration caused reduction in germination and early seedling growth. Germination and its rate were strongly inhibited with the increase of salt concentration (Figures 1A, 1B). This might be due to the fact that high amounts of $\mathrm{NaCl}$ disturbed the ionic balance of plant cells and also caused imbalances in plant nutrients, which affect the germination percentage, germination rate and plant growth. Germination rate and the final seed germination slow down with the decrease of the water movement into the seeds during imbibitions (Hadas, 1977). Germination failures under saline soils are often the re- 

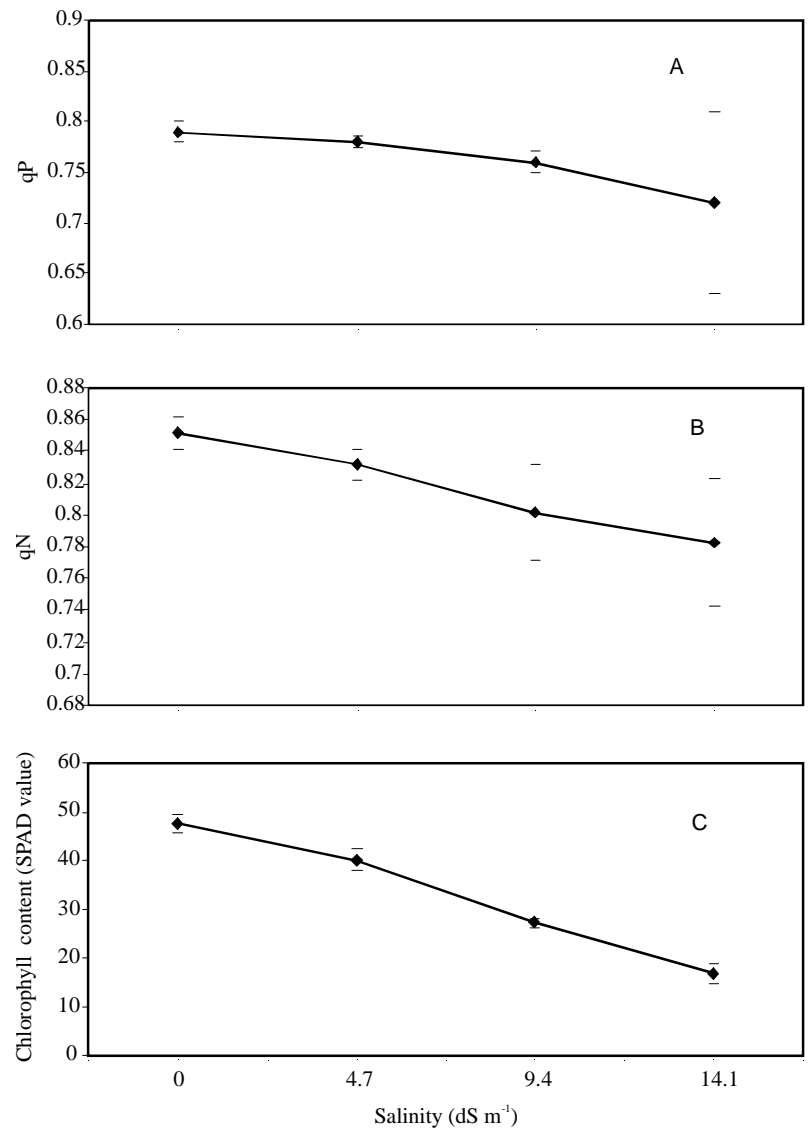

Figure 4 - Salinity effect on photochemical quenching (A) nonphotochemical quenching (B) and chlorophyll content (C) at various Na concentrations for radish (Raphanus sativus L.).

sults of high salt concentrations in the seed planting zone because of upward movement of soil solution and subsequent evaporation at the soil surface (Bernstein, 1974). Salt induced inhibition of seed germination could be attributed to osmotic stress or to specific ion toxicity (Huang \& Redmann, 1995). Germination percentage decreased as the level of salinity of the medium increased (Mauromicale \& Licandro, 2002, Gulzar et al., 2001).

The root and shoot lengths are the most important traits for salt stress because roots are in direct contact with the soil and absorb its water for shoot supply. For this reason, root and shoot lengths provide an important clue to the response of plants to salt stress (Jamil \& Rha, 2004). Salinity reduced root and shoot lengths as the level of salt increased, however the decrease in the length of the root was more prominent as compared to the shoot (Figures 1C, 1D). Fresh weight of root and shoot was reduced by increasing salt levels, whereas fresh weight of shoot was reduced more then fresh root weight (Figures $2 \mathrm{~A}$ and $2 \mathrm{~B})$. The reason of the reduction in the root and shoot lengths may be due to the toxic effect of $\mathrm{NaCl}$ as well as to an imbalance of the nutrient amount in the plant. Some studies indicate that the plant has a reduction in its growth due to the proportional increase of Na. High salinity may inhibit root and shoot elongation due to the lower water uptake by the plant (Werner \& Finkelstein, 1995). Demir \& Arif (2003) observed that the root growth was more adversely affected as compared to shoot growth by salinity. Jeannette et al. (2002) reported that total fresh weight of root and shoot of cultivated accessions was reduced with increased salt stress.

Maximal quantum yield of PS2 (Fv/Fm), photochemical quenching coefficient $\left(\mathrm{q}_{\mathrm{p}}\right)$ and non-photochemical quenching coefficient $\left(\mathrm{q}_{\mathrm{N}}\right)$ were reduced as the salt level increased, and no effect of salinity was found on ETR, Fo/Fm and Fv'/Fm'(Figures 3, 4). The reduction of chlorophyll fluorescence is associated with the increased $\mathrm{Na}$ accumulation (Dionisio-Sese \& Tobita, 2000). The inhibition of the photochemical quenching coefficient $\left(\mathrm{q}_{\mathrm{p}}\right)$ by $\mathrm{NaCl}$ may be a consequence of stomatal closure by salinity induction, caused by the reduction in osmotic potential. The major process involved in the protection against photo damage is probably the photochemical quenching energy dissipation, which reduces the relative quantum yield of PS2 in order to maintain an adequate balance between photosynthetic electron transport and carbon metabolism (Weis \& Berry, 1987; Krause \& Weis, 1991). Reduction in photosynthesis by increased salinity could be due to lower stomatal conductance, depression of specific metabolic processes in the carbon uptake, inhibition in photochemical capacity, or a combination of these (Seemann \& Critchley, 1985; Dubey, 1997). Salt decreases efficiency of photosynthesis (Hasegawa et al., 2000; Munns, 2002; Ashraf \& Shahbaz, 2003).

Plant exposed to saline environment generally has the leaf area reduced. In the present study, salinity reduced the leaf area and chlorophyll content as the salinity level increased with no significant effect on leaf water content (Figures 2, 4). Salt stress reduced the leaf growth rate by shortening the length of the leaf elongating zone and decreasing the growth intensity in its central and distal portions (Bernstein et al., 1993). Leaf growth inhibition by salinity must be expected to occur via an effect on this region (Lazof \& Bernstein, 1998). NaCl stress decreased total chlorophyll content of the plant by increasing the activity of the chlorophyll degrading enzyme: cholorophyyllase (Rao \& Rao, 1981), inducing the destruction of the chloroplast structure and the instability of pigment protein complexes (Sing \& Dubey, 1995). It has been reported that chlorophyll content decreases in salt susceptible plants such as tomato (Lapina \& Popov, 1970), pea (Hamada \& El-Enany, 1994), and soybean (Seemann \& Critchley, 1985) 
A positive relationship was observed between $\mathrm{Fv} / \mathrm{Fm}$ and $\mathrm{q}_{\mathrm{p}}$, leaf area and chlorophyll content but yield did not correlate with Fv'/Fm', Fo/Fm, ETR and $\mathrm{q}_{\mathrm{N}}$ (Table 1). A similar kind of relationship between Fv/Fm and $q_{p}$ was also observed by Seemann \& Critchley (1985), Dubey (1997), Weis \& Berry (1987) and Krause \& Weis (1991). The reduction in photosynthesis under salinity can also be attributed to a decrease in chlorophyll content (Delfine et al., 1999). The present data clearly support the general correlation between the photosynthetic capacity and leaf area, in agreement with the hypothesis of Reich et al. (1999) that no species can improve photosynthetic capacity without increasing leaf area due to biophysical limitations. Similar results were also observed by Schulze et al. (1994).

\section{ACKNOWLEDGEMENT}

To the Rural Development Administration (RDA), Korea in 2006.

\section{REFERENCES}

ASHRAF, M.; SHAHBAZ, M. Assessment of genotypic variation in salt tolerance of early CIMMYT hexaploid wheat germplasm using photosynthetic capacity and water relations as selection criteria. Photosynthetica, v.41, p.273-280, 2003.

BERNSTEIN, L. Crop growth and salinity. In: SCHIFFGAARDE, J.V. (Ed.). Drainage for agriculture. Madison: ASA, 1974. p.39-54. (Agronomy Monograph).

BERNSTEIN, N.; LAÜCHLI, A.; SILK, W.K. Kinematics and dynamics of sorghum (Sorghum bicolor L.) leaf development at various $\mathrm{Na} / \mathrm{Ca}$ salinities: I. Elongation growth. Plant Physiology, v.103, p.1107-1114, 1993.

DELFINE, S.; ALVINO, A.; VILLANA, M.C.; LORETO, F. Restriction to carbon dioxide and photosynthesis in spinach leaves recovering from salt stress. Plant Physiology, v.199, p.1101-1106, 1999.

DEMIR, M.; ARIF, I. Effects of different soil salinity levels on germination and seedling growth of safflower (Carthamus tinctoriusl). Turkish Journal of Agriculture, v.27, p.221227, 2003.

DIONISIO-SESE, M.L.; TOBITA, S. Effect of salinity on sodium content and photosynthetic responses of rice seedling differing in salt tolerance. Journal of Plant Physiology, v.157, p.5458,2000 .

DUBEY, R.S. Photosynthesis in plants under stressful conditions. In: PESSARAKLI, M. (Ed.). Handbook of photosynthesis. New York: Marcel Dekker, 1997. p.859-875.

GENTY, B.; BRIANTAIS, J.M.; BAKER, N.R. The relationship between the quantum yield of photosynthetic electron transport and quenching of chlorophyll fluorescence. Biochimica et Biophysica Acta, v.99, p.87-92, 1989.

GREENWAY, H.; MUNNS, R. Mechanisms of salt tolerance in nonhalophytes. Annual Review of Plant Physiology, v.31, p.149-190, 1980 .

GRIEVE, C.M.; SUAREZ, D.L. Purslane (Portulaca oleracea L.): a halophytic crop for drainage water reuse systems. Plant and Soil, v.192, p.277-283, 1997

GULZAR, S.; KHAN M.A.; UNGAR, I.A. Effect of salinity and temperature on the germination of Urochondra setulosa (Trin.) C. E. Hubbard. Seed Science and Technology, v.29, p.21-29, 2001 .
HADAS, A. Water uptake and germination of leguminous seeds in soils of changing matrix and osmotic water potential. Journal of Experimental Botany, v.28, p.977-985, 1977.

HAMADA, A.M.; EL-ENANY, A.E. Effect of $\mathrm{NaCl}$ salinity on growth, pigment and mineral element contents, and gas exchange of broad bean and pea plants. Biologia Plantarum, v.36, p.75$81,1994$.

HASEGAWA, P.M.; BRESSAN, R.A.; ZHU, J.K.; BOHNERT, H.J. Plant cellular and molecular response to high salinity. Annual Review of Plant Physiology and Plant Molecular Biology, v.51, p.463-499, 2000.

HOAGLAND, D.R.; ARNON, D.I. The water-culture method of growing plants without soil. Berkeley: California Agriculture Experiment Station, 1950. 32p. (Circular, 347)

HUANG, J.; REDMANN, R.E. Physiological response of canola and wild mustard to salinity and contrasting calcium supply. Journal of Plant Nutrition, v.18, p.1931-1949, 1995.

JAMIL, M.; RHA, E.S. The effect of salinity $(\mathrm{NaCl})$ on the germination and seedling of sugar beet (Beta vulgaris L.) and cabbage (Brassica oleracea capitata L.). Korean Journal of Plant Resources, v.7, p.226-232, 2004.

JEANNETTE, S.; CRAIG, R.; LYNCH, J.P. Salinity tolerance of phaseolus species during germination and early seedling growth. Crop Science, v.42, p.1584-1594, 2002.

KRAUSE, G.H.; WEIS, E. Chlorophyll fluorescence and photosynthesis: the basics. Annual Review of Plant Physiology and Plant Molecular Biology, v.42, p.313-349, 1991.

LAPINA, L.P.; POPOV. B.A. Effect of sodium chloride on photosynthetic apparatus of tomatoes. Fiziologiya Rastenii, v.17, p.580-584, 1970.

LAZOF, D.; BERNSTEIN, N. The NaCl-induced inhibition of shoot growth: the case for disturbed nutrition with special consideration of calcium nutrition. Advances in Botanical Research, v.29, p. 113189,1998

LI, C.C. Introduction to experimental statistics. New York: McGraw Hill Book Company, 1964.

LONG, S.P.; BAKER, N.R. Saline terrestrial environments. In: BAKER, N.R.; LONG, S.P. (Ed.). Photosynthesis in contrasting environments. New York: Elsevier, 1986. p.63102.

MARCELIS, L.F.M.; HOOIJDONK, J.V. Effect of salinity on growth, water use and nutrient use in radish (Raphanus sativus L.). Plant and Soil, v.215, p.57-64, 1999.

MAUROMICALE, G.; LICANDRO, P. Salinity and temperature effects on germination, emergence and seedling growth of globe artichoke. Agronomie, v.22, p.443-450, 2002.

MUUNS, R. Physiological processes limiting plant growth in saline soil: some dogmas and hypothese. Plant, Cell and Environment, v.16, p.15-24, 1993.

MUNNS, R. Comparative physiology of salt and water stress. Plant, Cell and Environment, v.25, p.239-250, 2002.

MUNNS, R.; TERMAAT, A. Whole plant responses to salinity. Australian Journal of Plant Physiology, v.13, p.143-160, 1986.

NEUMANN, P.M. Inhibition of root growth by salinity stress: Toxicity or an adaptive biophysical response. In: BALUSKA, F.; CIAMPOROVA, M.; GASPARIKOVA, O.; BARLOW, P.W. (Ed.). Structure and function of roots. Dordrecht: Kluwer Academic Publishers, 1995. p.299-304.

RAO, G.G.; RAO, G.R. Pigment composition \& chlorophyllase activity in pigeon pea (Cajanus indicus Spreng) \& Gingelley (Sesamum indicum L.) under $\mathrm{NaCl}$ salinity. Indian Journal of Experimental Biology, v.19, p.768-770, 1981.

REICH, P.B.; ELLSWORTH, D.S.; WALTERS, M.B.; VOSE, J.M.; GRESHAM, C.; VOLIN, J.C.; BOWMAN, W.D. Generality of leaf trait relationships: a test across six biomes. Ecology, v.80, p.1955-1969, 1999 .

ROUNDY, B.A. Root penetration and shoot elongation of tall wheatgrass and basin wild rye in relation to salinity. Canadian Journal of Plant Science, v.65, p.335-343, 1985. 
SCHULZE, E.D.; KELLIHER, F.M.; KÖRNER, C.; LLOYD, J.; LEUNING, R. Relationships among maximum stomatal conductance, ecosystem surface conductance, carbon assimilation rate, and plant nitrogen nutrition: a global ecology scale exercise. Annual Review of Ecology and Systematics, v.25, p.629-660, 1994.

SEEMANN, J.R.; CRITCHLEY, C. Effects of salt stress on the growth, ion content, stomatal behaviour and photosynthetic capacity of a salt-sensitive species, Phaseolus vulgaris L. Planta, v.164, p.151-162, 1985.

SHANNON, M.C.; GRIEVE, C.M.; FRANCOIS, L.E. Whole-plant response to salinity. In: WILKINSON R.E. (Ed.). Plantenvironment interactions. New York: Marcel Dekker, 1994 p. 199-244.
SINGH, A.K.; DUBEY, R.S. Changes in chlorophyll $a$ and $b$ contents and activities of photosystems 1 and 2 in rice seedlings induced by NaCl. Photosynthetica, v.31, p.489-499, 1995.

WEIS, E.; BERRY, J.A. Quantum efficiency of photosystem II in relation to energy-dependent quenching of chlorophyll fluorescence. Biochimica et Biophysica Acta, v.894, p.198208, 1987.

WERNER, J.E.; FINKELSTEIN, R.R. Arabidopsis mutants with reduced response to $\mathrm{NaCl}$ and osmotic stress. Physiology of Plant, v.93, p.659-666, 1995

Received October 17, 2005

Accepted December 12, 2006 